\title{
Characteristics and risk factors for typhoid fever after the tsunami, earthquake and under normal conditions in Indonesia
}

\author{
Agung Budi Sutiono*1,2, Andri Qiantori ${ }^{1}$, Hirohiko Suwa and Toshizumi Ohta
}

\begin{abstract}
Background: Although typhoid transmitted by food and water is a common problem in daily life, its characteristics and risk factors may differ in disaster-affected areas, which reinforces the need for rapid public health intervention. Surveys were carried out post-tsunami in Banda Aceh, post-earthquake in Yogyakarta, and under normal conditions in Bandung, Indonesia. Logistic regression analysis was used to assess the risk factors with the dependent variable of typhoid fever, with or without complications.

Findings: Characteristic typhoid fever with complications was found in 5 patients (11.9\%) affected by the tsunami in Aceh, 8 (20.5\%) after the earthquake in Yogyakarta, and 13 (18.6\%) in Bandung. After the tsunami in Aceh, clean water $(\mathrm{OR}=0.05 ; 95 \% \mathrm{Cl}: 0.01-0.47)$ and drug availability $(\mathrm{OR}=0.23 ; 95 \% \mathrm{Cl}: 0.02-2.43)$ are significant independent risk factors, while for the earthquake in Yogyakarta, contact with other typhoid patients $(\mathrm{OR}=20.30 ; 95 \% \mathrm{Cl}: 1.93-213.02)$ and education ( $\mathrm{OR}=0.08 ; 95 \% \mathrm{Cl}: 0.01-0.98)$ were significant risk factors. Under normal conditions in Bandung, hand washing ( $\mathrm{OR}=0.07 ; 95 \% \mathrm{Cl}: 0.01-0.50)$ and education ( $\mathrm{OR}=0.08 ; 95 \% \mathrm{Cl}: 0.01-0.64)$ emerged as significant risk factors.
\end{abstract}

Conclusion: The change in risk factors for typhoid complication after the tsunami in Aceh and the earthquake in Yogyakarta emphasizes the need for rapid public health intervention in natural disasters in Indonesia.

\section{Background}

On December 26, 2004, an earthquake that measured 9.0 on the Richter scale occurred $150 \mathrm{~km}$ off the coast of Sumatra-Indonesia in the Indian Ocean, and triggered a widespread tsunami that hit Aceh 45 minutes later and devastated an $800-\mathrm{km}$ coastal strip. Approximately 130,000 people died, and a further 37,000 went missing presumed dead [1]. On May 27, 2006, an 5.9 on the Richter scale earthquake struck about $25 \mathrm{~km}$ south-southwest of Yogyakarta city, which affected 36,299 people, with 5782 fatalities, and caused damage to 135,000 homes $[2,3]$.

Infectious diseases are an additional problem in disaster-affected areas [4]. Typhoid fever may cause serious complications after a disaster. It is a water-borne disease due to contaminated S. typhi in human excreta and trans-

\footnotetext{
*Correspondence: agungbudis@ohta.is.uec.ac.jp

${ }^{1}$ The University of Electro-Communications, Graduate School Information Systems, Graduate Department Social Intelligence and Informatics, 1-5-1 Chofugaoka, Chofu-shi, Tokyo, 182-8585 Japan

Full list of author information is available at the end of the article
}

mitted via hands [5]. Post-disaster typhoid fever outbreaks were reported in Puerto Rico following Hurricane Betsy in 1956 and in Mauritius following a cyclone in 1980 [6]. The biggest epidemic of typhoid fever following a complex disaster in two decades occurred in Tajikistan in 1992-1997, during which, around 21,000 internally displaced persons (IDPs) were created [7]. After a natural disaster in Calamba, near Manila, Philippines in March 2008, approximately 1400 people displayed typhoid symptoms, with the most serious complications being intestinal bleeding and typhoid perforation [8].

During these disasters, there are usually disruption of availability of clean water for food preparation and hand washing as well disruption of existing medical services $[4,9]$. The characteristics and risk factors of typhoid fever with complications in tsunami and earthquake might have different risk factors compared with the normal situation. The analysis, surveillance and control of risk factors for infectious diseases are important functions in public health $[10,11]$. The lack of facilities, difficult access to health services, and changing risk factors emphasize 
the need for rapid public health intervention to prevent typhoid fever in disaster-affected areas.

\section{Methods}

\section{Study area}

Typhoid fever patients were interviewed in three districts: post-tsunami Banda Aceh; post-earthquake Bantul, Yogyakarta; and Bandung under normal circumstances (Figure 1). Demographically, Banda Aceh city is occupied by 220,737 inhabitants with a population density 4.25 per $\mathrm{km}^{2}$ [12,13]. Bantul county, Yogyakarta has 813,087 inhabitants in an area of $3186 \mathrm{~km}^{2}$, with a population density of 255.21 per $\mathrm{km}^{2}$ [12]. Bandung city has $2,510,982$ inhabitants in an area of $34,597 \mathrm{~km}^{2}$, with a population density of 72.58 per $\mathrm{km}^{2}[14]$.

\section{Variables definition}

We defined the independent variables based on a previous study, namely age, sex, educational level, clean water, hand washing, contact with other typhoid patients [15], and typhoid complications/no complications as dependent variables. Educational level was classified as primary school (up to junior high school level, which is compulsory in Indonesia [16]), and secondary school (senior high school level and above). Rechecking variables is depending on patient behavior. Doctors suggest that patients submit themselves for rechecking after being discharged home, and it is up to the patients to decide to go. Drug availability seems to be a problem in disaster areas, in relation to where patients can obtain the required drugs and in administering them correctly. The first drugs of choice for S. typhi are chloramphenicol, ampicillin, ciprofloxacin and third-generation cephalosporins [17]. Since typhoid fever is water-borne, clean water is important, and drinking water from sources such as wells and municipal water points should be boiled before being drunk. Clean water checking involves ascertaining whether there is a chlorination program, and bacterial examination of water samples in the disaster-affected area. Patients should wash their hands in clean water before eating [18]. Contact with other typhoid patients refers to contact time of $>14$ days when patients stayed with relatives/friends or with a typhoid patient and shared food from the same plate [19]. Typhoid complications refer to the manifestations of typhoid fever, whether intra- and/or extra-intestinal (such as intestinal bleeding, typhoid perforation, toxic typhoid, and typhoid encephalopathy) [20-23].

\section{Data collection and selection criteria}

Permission to perform the study was obtained from Zainoel Abidin Hospital in Banda Aceh, Bantul Health Office in Yogyakarta, and Hasan Sadikin Hospital, Bandung. Typhoid fever was confirmed by positive blood/bone marrow/feces culture for S. typhi [19]. Patient data were taken from their medical records, and a survey was subsequently conducted to verify the disaster situation. The questionnaire was developed based on previous studies $[15,19,24]$ and tested in small samples (20 individuals from Banda Aceh, Yogyakarta and Bandung). The selection criteria flowchart is shown in Figure 2. Informed consent was obtained from the respondents. All respon-

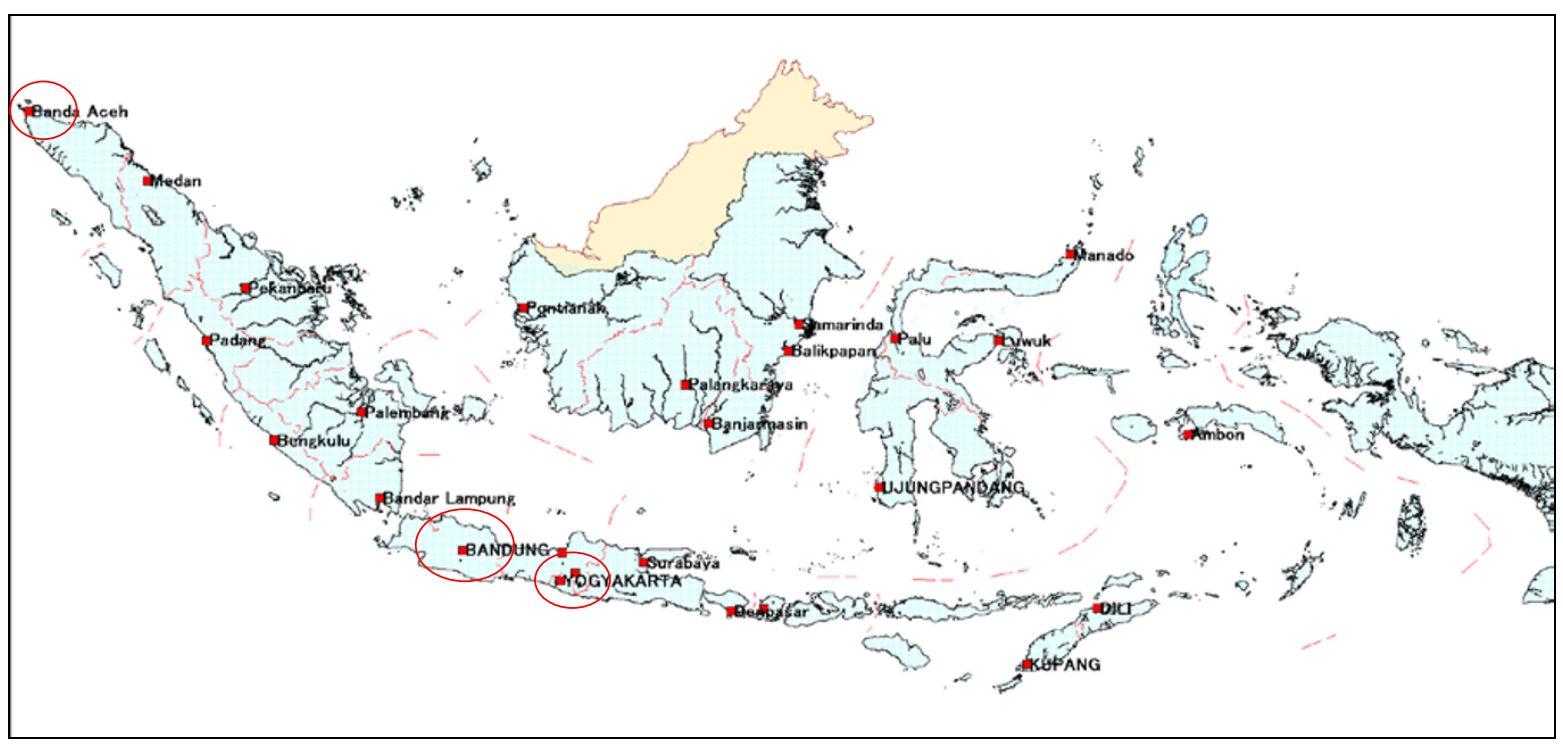

Figure 1 Study area typhoid fever with complications in post-tsunami (Aceh), post-earthquake (Yogyakarta) and normality (Bandung), Indonesia. Source: Geology and oceanography research centre, Indonesia. 


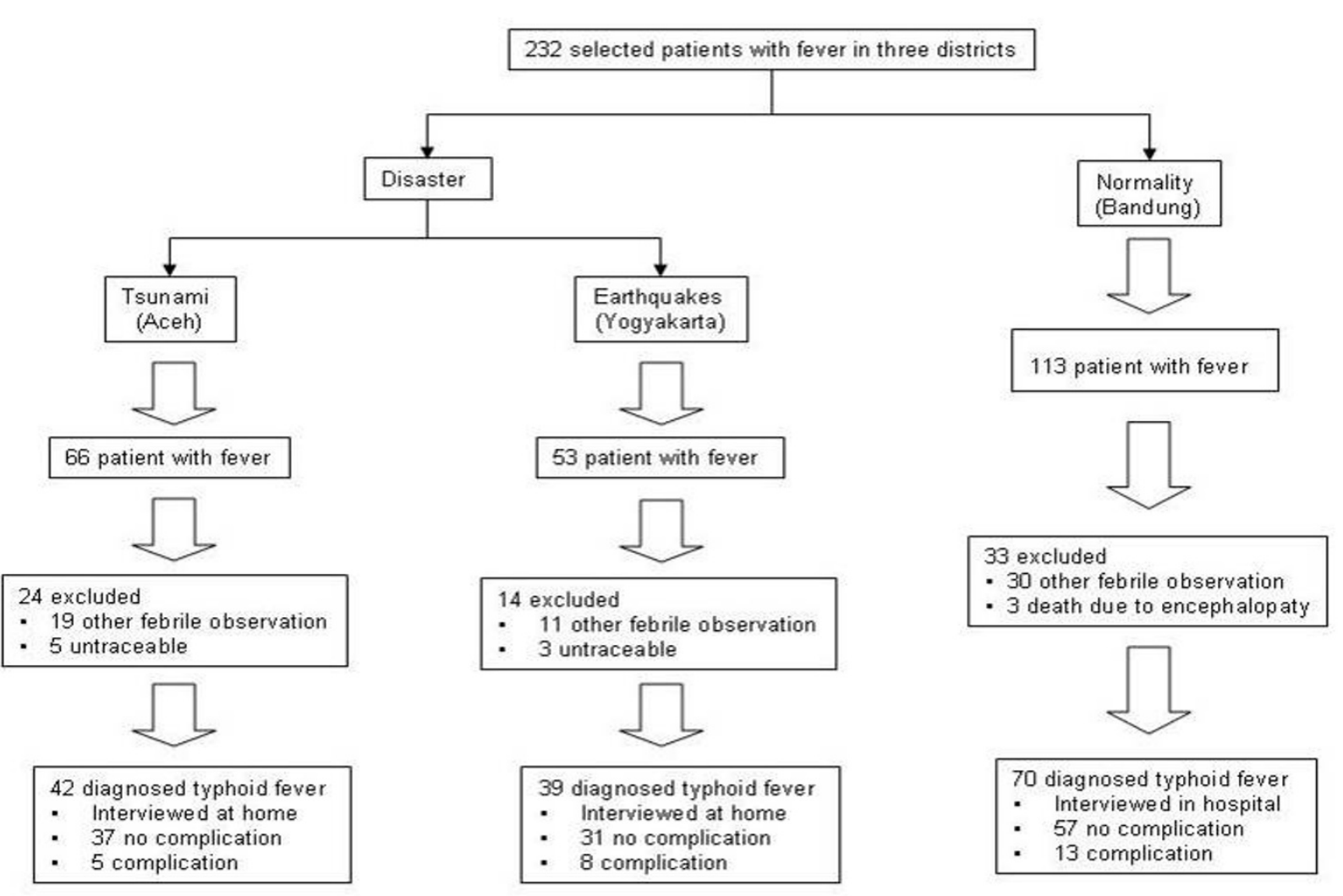

Figure 2 Selection criteria typhoid fever with complications

dents answered our questionnaire after giving their informed consent. For questions to children aged $<13$ years, responses were given by their mother or other family members, who were fully aware of the condition of their children during hospitalization and discharge. Brief training and explanation of the study were given to the students from Syiah Kuala University Banda Aceh, Gajah Mada University Yogyakarta, and Padjadjaran University Hasan Sadikin Hospital, Bandung before surveillance and interviewing respondents. Socio-cultural issues and customs vary between provinces in Indonesia, and this had to be taken into account. Data were stored anonymously and confidentially.

\section{Interview}

This interview was conducted because of the lack of disaster information in medical records. The participants in all the three groups responded to the same questionnaire after giving their informed consent. The responses of the patients were used to obtain a full description of the disease and disaster situation. The questionnaires were used to guide the interviewers to explore the patients' experiences retrospectively. Sample questions were as follows:
- "Did the doctor suggest that you to go for a check-up after recovery?"

- "Did you go for a check-up as the doctor suggested?"

- "Did you obtain the required drugs and take them correctly?"

- "Did you obtain clean water and check that it was clean?"

- "Did you wash your hands before eating?"

- "Did you have contact with other typhoid patients?"

The responses were coded as 0 for "no" and 1 for "yes".

\section{Statistical analysis}

The typhoid variables from the questionnaires were entered on a Microsoft Excel 2003 spreadsheet, and SPSS version 17.0 was applied for logistic regression analysis to determine the significant independent risk factors for typhoid complications in each district.

\section{Results}

In Aceh, data were collected 2 months after the tsunami, in Yogyakarta, 1 month after the earthquake, and in Bandung, data were collected from August 2006 to January 2007. There was different time duration due to it was related to the rehabilitation and reconstruction phase 
Table 2: Type of complications on typhoid fever

\begin{tabular}{lll}
\hline $\begin{array}{l}\text { Post tsunami (Aceh) } \\
\mathbf{n = 5}\end{array}$ & $\begin{array}{l}\text { Post earthquake (Yogyakarta) } \\
\mathbf{n = 8}\end{array}$ & $\begin{array}{l}\text { Normality (Bandung) } \\
\mathbf{n}=\mathbf{1 3}\end{array}$ \\
\hline 2 Intestinal bleeding & 4 Intestinal bleeding & 2 Intestinal bleeding \\
2 Typhoid perforation & 1 Typhoid perforation & 3 Typhoid perforation \\
1 Typhoid Toxic & 3 Typhoid Encephalopaty & 4 Typhoid Encephalopaty \\
& & 4 Typhoid Toxic \\
\hline
\end{tabular}

after disaster compare to the normal situation. We found 232 patients with fever in the three districts. There were 66 post-tsunami patients in Banda Aceh. Nineteen patients were excluded because of negative blood/bone marrow/feces culture for $S$. typhi, and 5 were untraceable because of an unclear address, or they had moved house. Therefore, the final number of patients interviewed was 42, including 5/42 (11.9\%) with typhoid complications. A similar pattern emerged in Yogyakarta, where there were 53 patients with fever; 14 were excluded and 39 were interviewed, including 8/39 (20.5\%) with typhoid complications. Under normal conditions at Bandung, we found 113 cases of typhoid, with 33 patients excluded and 70 interviewed, including 13/70 (18.6\%) with complications (Figure 2). Three patients died from typhoid encephalopathy due to came to the hospital in the late stage of illness.

The subject characteristics for typhoid cases in the three districts are presented in Table 1. The mean ages in Aceh, Yogyakarta and Bandung were $36.1 \pm 15.4$ years (interquartile range 26), $35.5 \pm 14.5$ years (interquartile range 21) and $19.3 \pm 13.7$ years (interquartile range 54), respectively. In the Aceh tsunami and the Yogyakarta earthquake, the number of male patients dominated, with $25(59.5 \%)$ and 20 (56.4\%), respectively. On the other hand, Bandung had more female patients, at 42 (60.0\%). Complications emerged in 5 cases, 4 male (9.5\%) and 1 female (2.2\%) after the Aceh tsunami, 8 cases with 5 male (12.8\%) and 3 female (7.7\%) after the Yogyakarta earthquake, and 13 cases with 4 male (5.7\%) and 9 female (12.9\%) in Bandung under normal circumstances.

Table 2 describes the type of complications that occurred post-tsunami in Aceh, post-earthquake in Yogyakarta, and under normal circumstances in Bandung. In Aceh, the complications included 2 cases of intestinal bleeding, 2 of typhoid perforation and 1 of toxic typhoid. In Yogyakarta, we found 4 cases of intestinal bleeding, 1 of typhoid perforation, and 3 of typhoid encephalopathy. In Bandung, there were 2 cases of intestinal bleeding, 3 of typhoid perforation, 4 of typhoid encephalopathy, and 4 of toxic typhoid. Patients with intestinal bleeding

Table 1: Characteristic of typhoid fever patients in three districts

\begin{tabular}{|c|c|c|c|c|}
\hline Variables & Classification & $\begin{array}{r}\text { Tsunami (Aceh) } \\
n=42[\%]\end{array}$ & $\begin{array}{r}\text { Earthquake } \\
\text { (Yogyakarta) } \\
n=39[\%]\end{array}$ & $\begin{array}{r}\text { Normality (Bandung) } \\
\qquad \mathbf{n}=70[\%]\end{array}$ \\
\hline \multirow[t]{2}{*}{ Age [years] } & Mean \pm SD & $36.1 \pm 15.4$ & $35.5 \pm 14.5$ & $19.3 \pm 13.7$ \\
\hline & Interquartile range & 26 & 21 & 54 \\
\hline \multirow[t]{2}{*}{ Gender } & Male & 25 [59.5] & $20[56.4]$ & $28[40.0]$ \\
\hline & Female & $17[40.5]$ & 19 [43.6] & $42[60.0]$ \\
\hline \multirow[t]{2}{*}{ Education } & Primary & $13[31.0]$ & $22[56.4]$ & $47[67.1]$ \\
\hline & Secondary & $29[69.0]$ & $17[43.6]$ & $23[32.9]$ \\
\hline \multirow[t]{2}{*}{ Complications } & Male & $4[9.5]$ & $5[12.8]$ & $4[5.7]$ \\
\hline & Female & $1[2.2]$ & $3[7.7]$ & $9[12.9]$ \\
\hline Recheck & & $38[90.5]$ & 36 [92.3] & $64[91.4]$ \\
\hline Go to recheck & & $30[71.4]$ & $30[76.9]$ & $51[72.9]$ \\
\hline Drug availability & & 28 [66.7] & $28[71.8]$ & $50[71.4]$ \\
\hline Clean water & & $34[81.0]$ & $32[82.1]$ & $58[82.9]$ \\
\hline Water checking & & 10 [23.8] & $9[23.1]$ & $15[21.4]$ \\
\hline Hand washing & & $38[90.5]$ & 35 [89.7] & $64[91.4]$ \\
\hline $\begin{array}{l}\text { Contact with other } \\
\text { typhoid }\end{array}$ & & 19 [45.2] & $17[43.6]$ & $36[51.4]$ \\
\hline
\end{tabular}


explained that their chief complaints included occult bleeding in their stools and acute abdominal symptoms associated with typhoid perforation. Meanwhile, the chief complaint of patients with typhoid encephalopathy and toxicity was a loss of consciousness.

In Table 3, bivariate correlation analysis showed that education ( $\mathrm{p}=0.01)$, drug availability $(\mathrm{p}<0.01)$ and clean water $(\mathrm{p}<0.01)$ were significant for typhoid complications after the tsunami in Aceh. After the earthquake in Yogyakarta, education $(\mathrm{p}=0.05)$ and contact with other typhoid fever patients $(\mathrm{p}<0.01)$ were found to be significant. Under normal conditions in Bandung, the significant bivariate correlation was for education $(\mathrm{p}=0.05)$, drug availability $(\mathrm{p}=0.03)$ and hand washing $(\mathrm{p}=0.01)$.

As shown on Table 4, the logistic regression analysis revealed that clean water $(\mathrm{OR}=0.05,95 \% \mathrm{CI}$ : 0.01-0.47) and drug availability (OR:0.23, 95\%CI: 0.02-2.43) were significant risk factors after the tsunami in Aceh, and contact with other typhoid patients $(\mathrm{OR}=20.30,95 \% \mathrm{CI}$ : 1.93-213.02) and education (OR $=0.08,95 \% \mathrm{CI}$ : $0.01-0.98)$ were significant after the earthquake in Yogyakarta. Under normal conditions in Bandung, we found that hand washing (OR $=0.07,95 \% \mathrm{CI}: 0.01-0.50)$ and education $(\mathrm{OR}=0.08,95 \% \mathrm{CI}$ : 0.01-0.64) were significant risk factors.

\section{Discussion}

The main finding of this study was that there were different characteristics and risk factors associated with typhoid complications after the tsunami in Aceh, after the earthquake in Yogyakarta, and under normal conditions in Bandung (Tables 1, Table 2). The risk factors after the tsunami were lack of clean water and availability of drugs. These factors might have increased the risk of typhoid complications at the time when the level of destruction caused by the tsunami was large $[2,25,26]$. The tsunami destroyed the usual sources of clean water in Aceh, e.g. wells, municipal water and other clean water sources. Therefore the proposal of developing a portable clean water device for tsunami disaster event will be useful. Transmission of S. typhi was introduced into the camps of IDPs as a result of their inability to carry out proper food preparation, which was associated with the need for clean water, or bacterial contamination of drinking water [1]. Consistent with this disaster situation caused by the tsunami, the independent risk factors for IDPs included problems with drug distribution and availability. This was because destruction of all the main roads, bridges, sea ports, and airports rendered surface transportation impossible, and reconstructing such facilities took considerable time. At the time, there was only

Table 3: Bivariate correlation analysis with grouping variable complication and non complication

\begin{tabular}{|c|c|c|c|c|c|c|c|c|c|c|c|c|}
\hline \multirow{3}{*}{ Variables } & \multicolumn{4}{|c|}{ Tsunami (Aceh) } & \multicolumn{4}{|c|}{ Earthquake (Yogyakarta) } & \multicolumn{4}{|c|}{ Normality (Bandung) } \\
\hline & \multirow[b]{2}{*}{ Sig. } & \multirow{2}{*}{$\begin{array}{l}\text { Mean } \\
\text { diff }\end{array}$} & \multicolumn{2}{|c|}{$95 \% \mathrm{Cl}$} & \multirow[b]{2}{*}{ Sig. } & \multirow{2}{*}{$\begin{array}{l}\text { Mean } \\
\text { Diff }\end{array}$} & \multicolumn{2}{|c|}{$95 \% \mathrm{Cl}$} & \multirow[b]{2}{*}{ Sig. } & \multirow{2}{*}{$\begin{array}{l}\text { Mean } \\
\text { diff }\end{array}$} & \multicolumn{2}{|c|}{$95 \% \mathrm{Cl}$} \\
\hline & & & Lower & Upper & & & Lower & Upper & & & Lower & Upper \\
\hline Age & 0.33 & 0.23 & -0.25 & 0.71 & 0.49 & 0.14 & -0.27 & 0.55 & 0.46 & -0.11 & 0.15 & -0.42 \\
\hline Gender & 0.84 & -1.48 & -16.53 & 13.57 & 0.22 & -6.97 & -18.30 & 4.36 & 0.87 & 0.67 & 4.25 & -7.81 \\
\hline Education & 0.01 & 0.56 & 0.14 & 0.98 & 0.05 & 0.39 & 0.00 & 0.78 & 0.00 & 0.40 & 0.14 & 0.13 \\
\hline Recheck & 0.41 & 0.12 & -0.17 & 0.41 & 0.58 & 0.06 & -0.16 & 0.28 & 0.34 & 0.08 & 0.09 & -0.09 \\
\hline $\begin{array}{l}\text { Go to } \\
\text { recheck }\end{array}$ & 0.66 & -0.09 & -0.54 & 0.35 & 0.29 & 0.18 & -0.16 & 0.52 & 0.32 & 0.14 & 0.14 & -0.14 \\
\hline $\begin{array}{l}\text { Drug } \\
\text { availability }\end{array}$ & 0.00 & 0.76 & 0.36 & 1.15 & 0.28 & -0.19 & -0.56 & 0.17 & 0.03 & 0.31 & 0.14 & 0.04 \\
\hline $\begin{array}{l}\text { Clean } \\
\text { water }\end{array}$ & 0.00 & 0.92 & 0.67 & 1.17 & 0.57 & 0.09 & -0.23 & 0.40 & 0.54 & 0.07 & 0.12 & -0.16 \\
\hline $\begin{array}{l}\text { Water } \\
\text { checking }\end{array}$ & 0.19 & 0.27 & -0.14 & 0.68 & 0.44 & 0.13 & -0.21 & 0.48 & 0.56 & 0.07 & 0.13 & -0.18 \\
\hline $\begin{array}{l}\text { Hand } \\
\text { washing }\end{array}$ & 0.41 & 0.12 & -0.17 & 0.41 & 0.82 & 0.03 & -0.22 & 0.28 & 0.00 & 0.27 & 0.08 & 0.11 \\
\hline $\begin{array}{l}\text { Contact } \\
\text { with } \\
\text { other } \\
\text { typhoid }\end{array}$ & 0.81 & 0.06 & -0.43 & 0.55 & 0.00 & -0.71 & -1.04 & -0.38 & 0.68 & 0.06 & 0.16 & -0.25 \\
\hline
\end{tabular}

Statistically significant associations are in bold 
Table 4: Risk factors by logistic regression analysis with dependent variable complication and non complication

\begin{tabular}{|c|c|c|c|c|c|c|c|c|c|}
\hline \multirow{3}{*}{$\begin{array}{l}\text { Risk } \\
\text { factors }\end{array}$} & \multicolumn{3}{|c|}{ Aceh } & \multicolumn{3}{|c|}{ Yogya } & \multicolumn{3}{|c|}{ Bandung } \\
\hline & \multirow[b]{2}{*}{ OR } & \multicolumn{2}{|c|}{ 95\% C.I. } & \multirow[b]{2}{*}{ OR } & \multicolumn{2}{|c|}{ 95\% C.I. } & \multirow[b]{2}{*}{ OR } & \multicolumn{2}{|c|}{ 95\% C.I. } \\
\hline & & Lower & Upper & & Lower & Upper & & Lower & Upper \\
\hline Age & 1.01 & 0.91 & 1.01 & 1.02 & 0.94 & 1.11 & 1.12 & 1.01 & 1.23 \\
\hline Gender & 0.74 & 0.05 & 0.74 & 0.37 & 0.03 & 4.41 & 1.13 & 0.22 & 5.86 \\
\hline Education & 0.61 & 0.01 & 0.61 & $* 0.08$ & 0.01 & 0.98 & $* 0.08$ & 0.01 & 0.64 \\
\hline Recheck & 0.01 & 0.00 & 0.1 & 1.30 & 0.01 & 121.36 & 1.10 & 0.04 & 27.16 \\
\hline $\begin{array}{l}\text { Go to } \\
\text { recheck }\end{array}$ & 6.15 & 0.15 & 6.15 & 0.37 & 0.02 & 6.156 & 0.81 & 0.12 & 5.26 \\
\hline $\begin{array}{l}\text { Drug } \\
\text { availability }\end{array}$ & $* 0.23$ & 0.02 & 2.43 & 1.22 & 0.06 & 23.21 & 0.35 & 0.07 & 1.64 \\
\hline Clean water & $* * 0.05$ & 0.01 & 0.47 & 0.42 & 0.02 & 6.86 & 0.78 & 0.09 & 6.32 \\
\hline $\begin{array}{l}\text { Water } \\
\text { checking }\end{array}$ & 1.19 & 0.03 & 1.19 & 0.57 & 0.04 & 8.70 & 0.89 & 0.14 & 5.69 \\
\hline $\begin{array}{l}\text { Hand } \\
\text { washing }\end{array}$ & 2.61 & 0.03 & 2.61 & 3.01 & 0.05 & 190.91 & $* 0.07$ & 0.01 & 0.50 \\
\hline $\begin{array}{l}\text { Contact } \\
\text { with other } \\
\text { typhoid }\end{array}$ & 3.15 & 0.12 & 3.15 & $* * 20.30$ & 1.93 & 213.02 & 0.73 & 0.16 & 3.34 \\
\hline
\end{tabular}

Significant level at $\mathrm{P}<0.05^{*}$ and $\mathrm{P}<0.01^{* *}$ (Statistically significant associations are in bold)

one way to distribute drugs and other logistics to the IDPs camp, namely by helicopter. The lack of typhoid drugs was not caused by the type of antibiotics involved, because there was government or non-government support for the first-line drugs of choice for typhoid fever (chloramphenicol, ampicillin, ciprofloxacin and thirdgeneration cephalosporins), but rather by the cumbersome distribution of the drugs.

After the earthquake in Yogyakarta, the significant risk factors included contact with other typhoid patients and education. Patients were unaware that S. typhi had infected their relatives or friends and this would only have emerged once the patient came to the medical facilities and was diagnosed with typhoid fever. Refer to the Indonesia Health Profile 2006 that the number of people who lacked any certificate education (not completed junior high school) in Yogyakarta was higher than in Aceh and Bandung (Figure 3). This may reflect the fact that educational level is a significant risk factor during an earthquake, as in Yogyakarta (Table 4). Therefore the rapid health promotion direct to the IDPs is necessary to reduce the risk of typhoid complication.

Under normal conditions in Bandung, we found that hand washing and education were significant risk factors. Hand washing may reflect different habits and behavior in society. The majority of those in west Java (Bandung) prefer to eat raw vegetables, [27] that sometimes are not properly washed, and followed by poor hand washing [28]. With this in mind, the government recently has promoted hand washing with soap as a national campaign in Indonesia to help prevent the infectious diseases such as typhoid complication [29]. Over 30\% of persons in Bandung have no educational certificate, according to the Indonesian Health Profile (Figure 3), which also emerged consistently as a significant independent risk factor for typhoid complications.

To reach conclusions concerning the distinct risk factors in each district, we compared characteristic cases of typhoid complications in Aceh, Yogyakarta and Bandung, based on the geographical and socio-demographic differences in a typical disaster (Figure 1). One of the reasons to determine the risk factors for typhoid complications are that the first-line drugs commonly used in Indonesia have become ineffective, thus hampering treatment of the condition $[17,30]$ and causing many complications [21$23,27]$ especially in disaster situation. The tsunami in Aceh was characterized by the high level of destruction, swift onrushing seawater that affected humans and the environment, the high probability of contamination of clean water, and the long time required for reconstruction/rehabilitation. The lack of clean water and available drugs were found to be related significantly to the other 


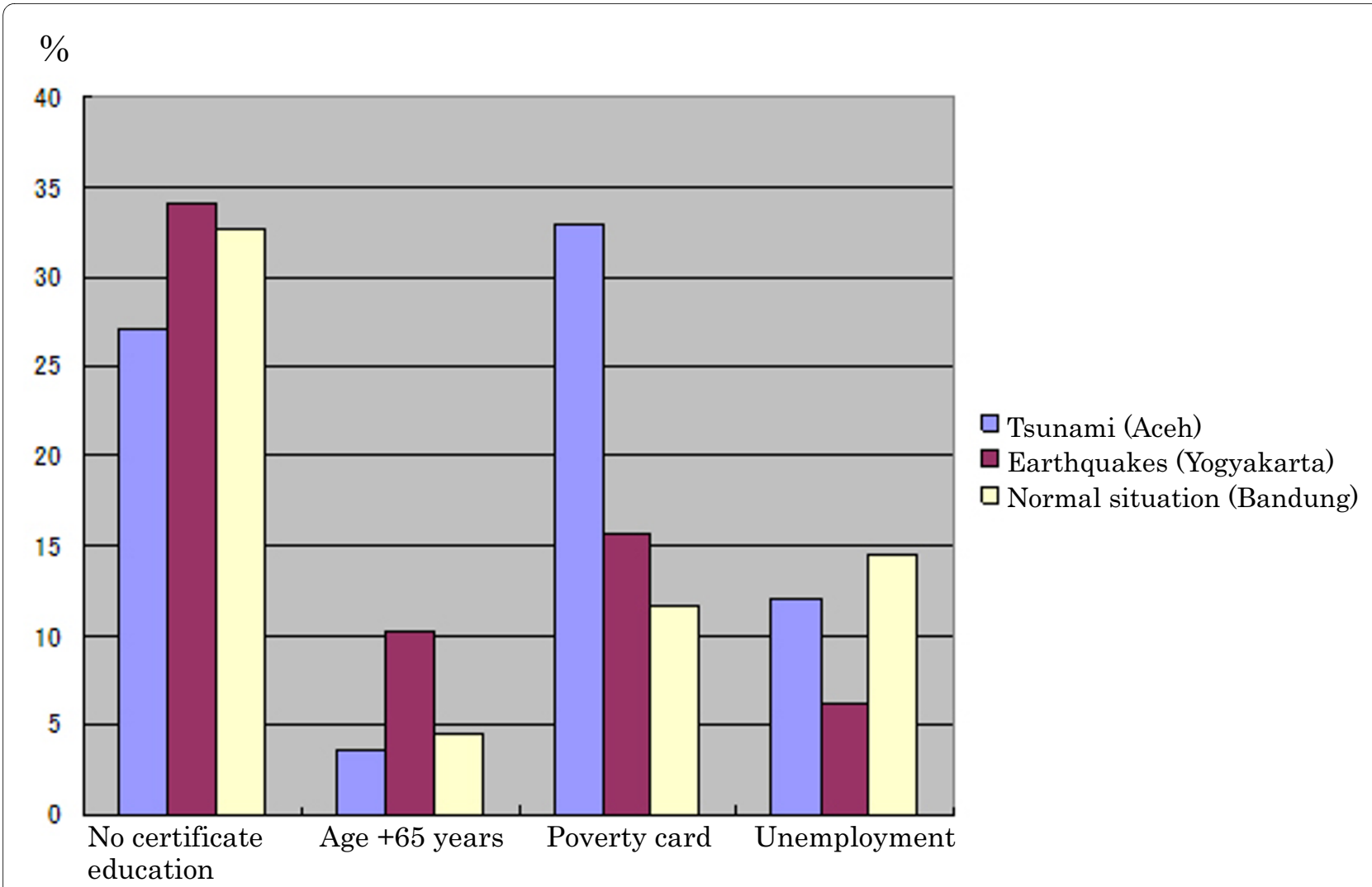

Figure 3 Characteristic socioeconomic in three districts. Source: Indonesian Health Profile 2006, Ministry of Health Indonesia.

tsunami background factors. In comparison, during the earthquake in Yogyakarta, there was no mass of water that was likely to cause contamination to wells, municipal water and other sources of drinking water. There was no mud after the earthquake and the level of destruction was also relatively low. However, although both calamities were mainly caused by earthquakes, geographically speaking, Aceh is located on the shoreline and Bantul, Yogyakarta is located in the middle of Java Island (Figure 1). Nevertheless, the population density in Yogyakarta was the highest (255.21 per $\mathrm{km}^{2}$ ) in this study (Table 5), which means that contact with others, like relatives or friends with typhoid fever seemed more frequent in Yogyakarta than in Aceh and Bandung [12]. Although Bandung is located in the centre of West Java, it is at an elevation of $765 \mathrm{~m}$ above sea level, which is higher than Yogyakarta and Aceh. Surrounded by mountains, Bandung has the potential for flooding in the rainy season [14], which increases the likelihood of typhoid transmission. The educational level may also influence personal habits and efforts to avoid typhoid fever with complications, such as a lack of awareness of and/or performing hand washing properly. These differences allowed us to determine the prevalence of risk factors between tsunami, earthquake and normal situation.
Patients were asked to describe their symptoms during hospitalization, as well those reported in the hospital. We found 42 patients with typhoid fever after the tsunami in Aceh, 5 of whom had complications (11.9\%). Two cases each of intestinal bleeding and typhoid perforation and one of toxic typhoid were reported as complications in the post-tsunami situation, which might be caused by the lack of drug availability and clean water distribution. The number of complications in Yogyakarta was 8 of 39 cases (20.5\%). We found four cases of intestinal bleeding, one of typhoid perforation and three of typhoid encephalopathy. However, there was not death case report in both of disaster situation. In Bandung, typhoid complications were found in 13 of 70 cases (18.6\%), with two of intestinal bleeding, three of typhoid perforation, four of typhoid encephalopathy, and four of toxic typhoid. The death cases were due to they came to the hospital on the late stage of disease. We excluded three fatalities caused by typhoid encephalopathy (Tables 2).

As shown in Table 3, education was a significant factor in bivariate correlation analysis in the three districts. However, there is no statistical different $(\mathrm{P}=0.42)$ for typhoid complication occurrence among three districts. Gasem et al in 2001 in Semarang [18] and Velema et al in 1997 in Ujung Pandang [15] reported that educational 
Table 5: Demographic profile in three districts

\begin{tabular}{lrrr}
\hline Variables & $\begin{array}{r}\text { Tsunami } \\
\text { (Aceh) }\end{array}$ & Earthquakes (Yogyakarta) & Normal Situation (Bandung) \\
\hline Population Province* & 4.031 .589 & 3.343 .651 & 38.965 .440 \\
Pop. City/county* & 220.737 & 813.087 & 2.510 .982 \\
City/county area km ${ }^{*}$ & 51.937 & 3.186 & 34.597 \\
Pop density $/ \mathrm{km}^{2}$ & 4,25 & 255,21 & 72,58 \\
\hline
\end{tabular}

*Source: BPS 2005 (Indonesian Statistical Bureau)

level was a significant risk factor for typhoid fever in Indonesia. A proposal to improve the quality of public education campaigns and stressing the importance of sanitation and hygiene whether in disaster or normal circumstances still appears to represent a realistic approach to infection prevention based on socio-cultural background limitation in our study.

\section{Conclusion}

Determination of the different risk factors of typhoid fever with complications after the tsunami in Aceh (availability of clean water and drugs) and after the earthquake in Yogyakarta (education level and avoiding contact with other typhoid patients) emphasizes the need for rapid public health intervention in complex disasters compared with normal circumstances in Indonesia.

\section{Competing interests}

The authors declare that they have no competing interests.

\section{Authors' contributions}

$\mathrm{AQ}$ and $\mathrm{HS}$ assisted the statistical analyses and interpreting the data. TO has given a suggestion how to choose the methodology analysis and involved in revising the manuscript critically before submission. Author and co-authors have read and approved the manuscript.

\section{Acknowledgements}

This study was supported by The Matsushita International Foundation and Ministry of Education, Culture, Sport, Science and Technology, Japan.

\section{Author Details}

1The University of Electro-Communications, Graduate School Information Systems, Graduate Department Social Intelligence and Informatics, 1-5-1 Chofugaoka, Chofu-shi, Tokyo, 182-8585 Japan and 2Hasan Sadikin Hospital, Padjadjaran University Faculty of Medicine, Jl. Pasteur 38 Bandung, 40161 Indonesia

Received: 1 December 2009 Accepted: 17 April 2010

Published: 17 April 2010

\section{References}

1. Watson JT, Gayer M, Connolly MA: Epidemics after natural disasters. Emerging Infectious Disease 2007 [http://www.cdc.gov/eid].

2. Wikipedia May 2006 Java earthquake [http://en.wikipedia.org/wiki/ May 2006 Java earthquake]

3. Sutiono AB, Qiantori A, Suwa H, Ohta T: Characteristic tetanus infection in disaster-affected areas: case study of the Yogyakarta earthquakes in Indonesia. BMC Research Notes 2009, 2:34.

4. Elias CJ, Alexander BH, Sokly T: Infectious disease control in a long-term refugee camp: The role of epidemiologic surveillance and investigation. Am J Public Health 1990, 80:824-828.
5. Flint S, Burd M, Bergin C, Jennings P, Keane M, Menon A, et al:: Centre for health protection surveillance case definitions of statutorily notifiable disease. Second edition. 2005:35.

6. Toole MJ: Communicable disease and diseas control. In The public health consequences of disasters Edited by: Noji EK. Oxord University Press US, New York; 1997:83.

7. Spiegel PB, Phuoc Le, Ververs MT, Salama P: Occurrence and overlap of natural disasters, complex emergencies and epidemics during the past decade (1995-2004). J Conflict and Health 2007, 1:2.

8. CBC [http://www.cbc.ca/health/story/2008/05/16/f-health-disasterdiseases.html]

9. Mori K, Ugai K, Nonami Y, et al.: Health needs of patients with chronic diseases who lived through the great Hanshin earthquake. J Disaster Management \& Response 2007, 5(1):8-13.

10. Dunn CE, Bhopal RS, Cockings S, Walker D, Rowlingson B, Diggle P: Advancing insight into methods for studying environmental-health relationships: a multidisciplinary approach to understanding Legionaires disease. J Health and Place 2007, 13:677-690.

11. Parrish HM, Baker AS, Bishop FM: Epidemiology in public health planning for natural disasters. Public health 1964, 79(10):863-867.

12. BPS (Indonesian Central Bureau of Statistics) [http://www.bps.go.id]

13. Aceh times, Indonesia [http://www.achehtimes.com]

14. Bandung City Official website [http://www.bandung.go.id]

15. Velema JP, Wijnen Gv, Bult P, Naerssen TV, Jota S: Typhoid fever in Ujung Pandang, Indonesia - High risk groups and high risk behaviours. Trop Med \& Int Health 1997, 2(11):1088-1094.

16. Hendaya S: Development of INSET model for improving teacher professionalism in Indonesia. J Int Edu Coop 2007, 2:97-106.

17. Hatta $M$, Ratnawati : Enteric fever in endemic areas of Indonesia: an increasing problem of resistance. J Infect Developing Countries 2008, 2(4):279-282.

18. Gasem MH, Dolmans WMV, Kauter M, Djokomouljanto R: Poor food hygiene and housing as risk factors for typhoid fever in Semarang, Indonesia. Trop Med and Int Health 2001, 6(6):484-490.

19. Vollaard AM, Ali S, AGH van Asten H, et al.: Risk factors for typhoid and Paratyphoid fever in Jakarta, Indonesia. J Am Med Assc 2004, 291(21):2607-15.

20. Huang DB, L Du Pont H: Problem pathogens: extra-intestinal complications of Salmonella enterica serotype Typhi infection. Lancet Infect Dis 2005, 5:341-348.

21. Hosoglu S, Aldemir M, Akalin S, et al.: Risk factors for enteric perforation in patients with typhoid fever. Am J Epidemiol 2004, 160:46-50.

22. Abantanga FA, Wiafe-Addai BB: Postoperative complications after surgery for typhoid perforation in children in Ghana. Pediatr Surg Int 1998, 14:55-58.

23. Mermin JH, Villar R, Carpenter J, et al:: A Massive of multidrug-resistant typhoid fever in Tajikistan associated with consumption of municipal water. J Infec Disease 1999, 179:1416-22.

24. Hayashi M, Kouzu H, Nishihara M, et al:: Acute renal failure likely due to acute nephritic syndrome associated with typhoid fever. Internal Medicine 2005, 44:1074-1077.

25. Leitmann : Cities and calamities: learning from post disaster response in Indonesia. J Urban Health 2007, 84(1):i144-i153.

26. Doocy S, Rofi A, Moodie C, et al:: Tsunami mortality in Aceh Province, Indonesia. Bulletin of world health organization 2007, 85(2):273-278.

27. Suganda [http://cetak.kompas.com/read/xml/2008/04/25/01154583/ orang.sunda.paling.suka.daun.muda2008] 
28. Alisjahbana A, Peeters R, Meheus A: Perinatal mortality and morbidity in rural west java Indonesia. Part l: viral statistics based on cross sectional surveys. Pediatr Indonesia 1990, 30(1-2):1-11.

29. ESP (Environmental Service Program) \& USAID 2007 [http://

www.esp.or.id/wp-content/uploads/pdf/news/news16id.pdf].

30. Bergh ETAM Van den, Gasem MH, Keuter M, Dolmans MV: Outcome in three groups of patients with typhoid fever in Indonesia between 1948 and 1990. Trop Med and Int Health 1999, 4(3):211-215.

doi: 10.1186/1756-0500-3-106

Cite this article as: Sutiono et al., Characteristics and risk factors for typhoid fever after the tsunami, earthquake and under normal conditions in Indonesia BMC Research Notes 2010, 3:106

Submit your next manuscript to BioMed Central and take full advantage of:

- Convenient online submission

- Thorough peer review

- No space constraints or color figure charges

- Immediate publication on acceptance

- Inclusion in PubMed, CAS, Scopus and Google Scholar

- Research which is freely available for redistribution

Submit your manuscript at www.biomedcentral.com/submit
() BioMed Central 